\title{
Proces, bezpieczeństwo procesu, systemy i układy bezpieczeństwa, układy sterowania, normowanie międzynarodowe i europejskie
}

\author{
Process, safety of process, safety control, control systems, \\ international and Europeans standards
}

\section{Streszczenie}

Bezpieczeństwo w przemyśle procesowym jest oceniane przez kilka parametrów: możliwość poważnych awarii z powodów technicznych, awarii z powodu katastrof środowiskowych, wypadków w trakcie transportu i magazynowania niebezpiecznych materiałów, sabotaży i ataków terrorystycznych, niepokojów społecznych.

Zadaniem systemów bezpieczeństwa jest eliminowanie możliwości powstania niebezpiecznych sytuacji. Ocena bezpieczeństwa zakładu procesowego należy do obowiązków inwestora oraz rządowych agencji. Chociaż zakłady procesowe są tak projektowane, aby były bezpieczne w czasie pracy oraz w przypadku awarii, nie można wykluczyć powstania sytuacji niebezpiecznych. Kierownictwa zakładów są odpowiedzialne za zapewnienie warunków bezpiecznej pracy zakładu oraz podejmowanie działań minimalizujących skutki możliwych katastrof.

Słowa kluczowe: proces; bezpieczeństwo procesu; systemy bezpieczeństwa; poziomy zabezpieczeń; normy związane z bezpieczeństwem

\begin{abstract}
The safety in process industry is assessed by various parameters: the possibility of serious accidents caused either by technology or human errors, accidents caused by environmental catastrophes, transport accidents, sabotage and terroristic assaults, accidents caused by improper storage of dangerous materials, and social unrest. Safety systems are created to eliminate the possibility of dangerous situations. National regulators and investors are responsible for the safety assessment of process industry. While process plants are designed to be safe in their regular operation and in the event of any malfunction, no industrial activity can be represented as entirely risk-free. Incidents and accidents can happen. The management of a plant is responsible for ensuring that the plant is operated safely by the licensee and should be ready to take action to minimize the results of catastrophic accidents.
\end{abstract}

Keywords: process; safety of process; safety control; control systems; international and europeans standards

\section{Wstęp}

Problemy i zagrożenia w przemyśle procesowym

Bezpieczeństwo przemysłowe przed okresem rozwoju automatyki i komputeryzacji skupiało się głównie na opracowywaniu zasad bezpiecznej pracy, na nadzorze nad niebezpiecznymi materiałami oraz wyposażeniu ochronnym pracowników. W dobie współczesnej zagadnienia bezpieczeństwa sięgają znacznie głębiej. Współczesne systemy bezpieczeństwa zmniejszając zagrożenia produkcyjne zwiększają niezawodność działania, produktywność oraz rentowność.

Problem bezpiecznej pracy instalacji lub maszyn jest postrzegany przez Unię Europejską jako podstawowa kwestia społeczna i przemysłowa. Jest ona szczególnie ważna w przypadku dużych i złożonych systemów technicznych, takich jak transport powietrzny czy kolejowy, przemysł zbrojeniowy, chemiczny albo energetyka jądrowa. Systemy te są najczęściej określane jako systemy procesowe. Bezpieczeństwo procesowe jest to ogół zagadnień dotyczących

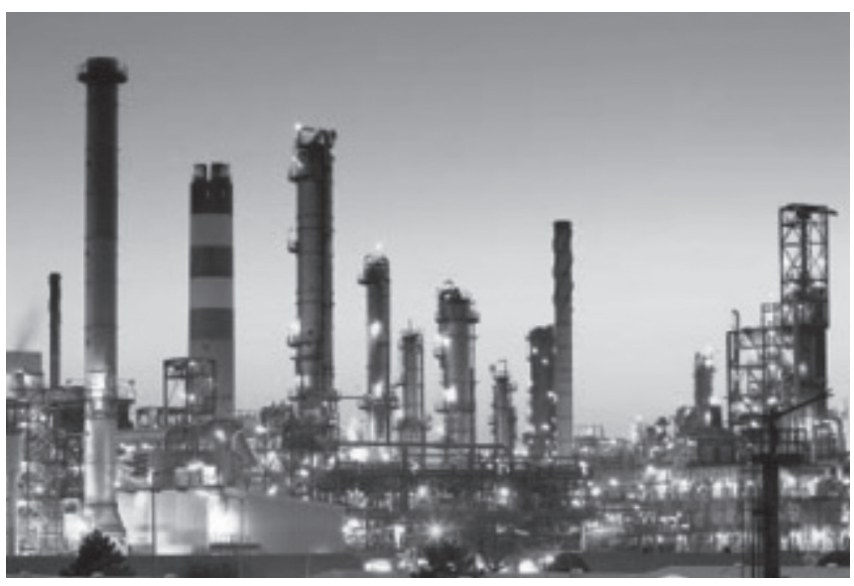

Rys. 1. Zdjęcie instalacji przemysłowej [3] Fig. 1. View of chemical plant

Dr inż. Wojciech Kramarek - Politechnika Warszawska, PWSZ Ciechanów.

Autor korespondencyjny/Corresponding author. kramarek@wip.pw.edu.pl 
bezpieczeństwa pracy instalacji przemysłowej w sektorze przemysłu procesowego (chemia, petrochemia, energetyka, gazownictwo). Wysokie temperatury i ciśnienia, palne i toksyczne materiały typowe dla tych gałęzi przemysłowych przyczyniają się do możliwości powstawania groźnych zagrożeń. Niezawodność elementów i systemów odpowiedzialnych za prowadzenie procesu wpływają na jego poprawną pracę oraz bezpieczeństwo.

Katastrofy w przemyśle procesowym powstają z następujących przyczyn:

a) technicznych:

- awarie techniczne elementów i systemów związanych z procesem produkcyjnym oraz bezpieczeństwem,

- uszkodzenia sensorów, elementów automatyki, maszyn i instalacji procesowych,

- obsługowe błędy ludzkie,

- zaniki zasilania energetycznego,

b) katastrof środowiskowych:

- trzęsienia ziemi,

- powodzie,

- wichury i huragany,

c) wypadki w trakcie transportu i magazynowania niebezpiecznych materiałów,

d) sabotaże i ataki terrorystyczne,

e) niepokoje społeczne.

Zagadnienia bezpieczeństwa procesowego mogą być podzielone na dwa działy:

1. minimalizacja ryzyka i zagrożeń procesowych na etapie projektu i postawania zakładu,

2. zarządzanie zagrożeniami oraz zachowania kryzysowe i powypadkowe.

Pojęcie "bezpieczeństwo" rozumiane jest jako brak niemożliwego do zaakceptowania zagrożenia dla zdrowia, życia lub strat w majątku czy środowisku naturalnym.

W zagadnieniach bezpieczeństwa używane jest często pojęcie ryzyka. Ryzyko w obszarze nauk technicznych jest rozumiane jako iloczyn prawdopodobieństwa wystąpienia danego zjawiska, skali strat (wielkości skutków niepożądanych) oraz ekspozycji (częstość narażania pracownika na sytuacje niebezpieczne).

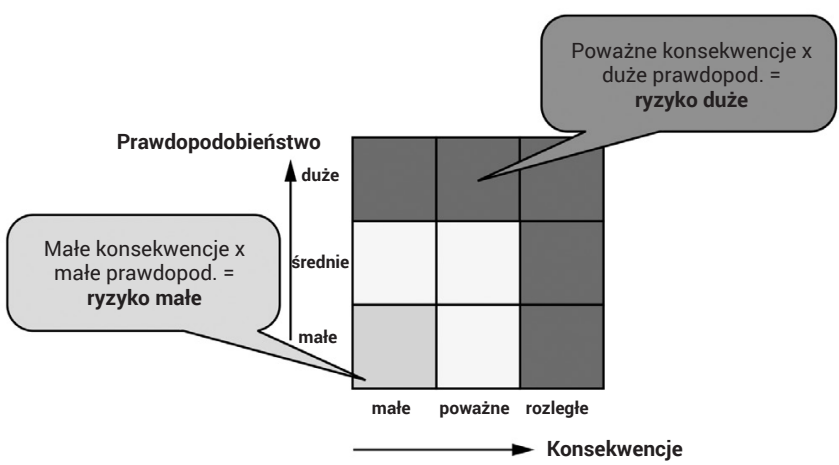

Rys. 2. Ryzyko jako funkcja sytuacji zagrożeń

Fig. 2. Industrial risk assessment

Wszystkie istniejące normy i przepisy związane z bezpieczeństwem mają za zadanie zmniejszenie istniejącego ryzyka, które jest nieodłącznie związane z procesami, produkcją, działaniem wyposażenia, transportem i magazynowaniem.

Osiągniecie absolutnego bezpieczeństwa w procesach przemysłowych jest nieosiągalne. Każda działalność przemysłowa niesie ze sobą określone zagrożenia. Istniejące ryzyko można zdefiniować jako pomijalne, tolerowalne lub nieakceptowane. Każdy tworzony układ związany z bezpieczeństwem musi doprowadzić ryzyko do poziomu pomijalnego lub tolerowanego. Przepisy zabraniają użytkowania układów wykazujących ryzyko nieakceptowane.
Cechą charakterystyczną przemysłu procesowego jest wymóg ciągłości procesów w przeciwieństwie do przemysłu maszynowego, w którym realizowane zadania (operacje, zabiegi) można zazwyczaj szybko przerwać. Jeśli przestoje maszyn nie są długie, straty wynikające z zatrzymania maszyny najczęściej są niewielkie. Straty powstałe w wyniku zatrzymania procesu są najczęściej bardzo kosztowne.

Zagrożenia istniejące w maszynach są znane i zdefiniowane. Większość zagrożeń występujących w instalacjach przemysłowych nie jest widoczna gołym okiem. Określenie stanu badanego procesu jest chwilami niemożliwe, ponieważ występują różne, mniej lub bardziej zbadane, stany przejściowe. Sytuację komplikuje ponadto wyjątkowo złożone zadanie, jakim jest określenie wielkości zdarzeń awaryjnych i oszacowanie ich skutków.

Pojęcie bezpieczeństwa procesowego i problem zapobiegania stratom wynikającym z awarii w instalacjach chemicznych, energetycznych i spożywczych pojawiły się na przełomie lat $60 \mathrm{i} 70 \mathrm{w}$ wyniku wystąpienia wielu poważnych awarii przemysłowych na terenie Europy i Stanów Zjednoczonych. Zdarzenia związane z bezpieczeństwem procesowym mogą mieć skutki katastroficzne i mogą powodować śmierć lud obrażenia pracowników na terenie zakładu oraz członków społeczności lokalnych poza terenem zakładu. Awarie mogą przyczynić się do znaczących zniszczeń w środowisku, na terenie zakładu lub poza zakładem.

\section{Przykłady katastrof w przemyśle procesowym}

Przykładem katastrofy w przemyśle procesowym może być wypadek w zakładach chemicznych Nypro Ltd we Flixborough w Wielkiej Brytanii w lipcu 1974. Fabryka produkowała głównie kaprolaktam, surowiec wykorzystywany do produkcji nylonu. W czasie produkcji z pękniętego rurociągu uwolniło się ok. 80 t. gorącego ciekłego cykloheksanu, którego pary utworzyły z powietrzem wybuchową mieszaninę. W wyniku eksplozji o sile równoważnej wybuchowi $30 \mathrm{t}$ trotylu śmierć poniosło 28 pracowników zakładu, a 36 osób odniosło obrażenia (rys. 3).

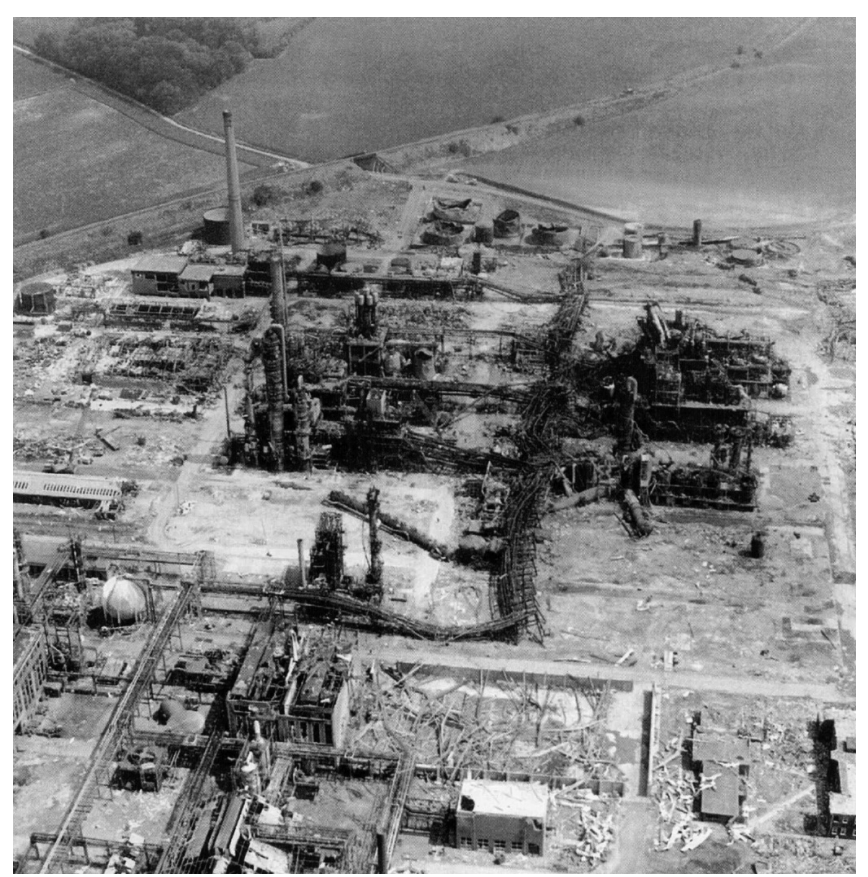

Rys. 3. Fabryka chemiczna w miejscowości Fixborough (Anglia) po wybuchu w lipcu 1974 r. [4]

Fig. 3. Chemical plant at Fixborough, England, after disaster in July, 1974 
W lipcu 1976 r. nastapiła groźna awaria w zakładach chemicznych w Sevesto, Włochy

Niespodziewany i niekontrolowany wzrost temperatury i ciśnienia w zbiorniku syntezy trójchlorofenylu doprowadził do uszkodzenia zaworu bezpieczeństwa. W wyniku awariinastąpił wyciek toksycznych gazów do atmosfery. Wiejący wiatr spowodował skażenie terenu gazami na długości 6 kilometrów i o szerokości jednego kilometra. Wypadkowi nadano nazwę katastrofa Sevesto. Chociaż w pierwszej chwili nie stwierdzono obrażeń ludzkich to w następnych dniach przeszło 200 osób trafiło do szpitali z powodu zatruć, tysiące zwierząt zdechło lub musiało być wybitych oraz została skażona gleba na obszarze 12 kilometrów kwadratowych.

Po katastrofie okazało się, że zarówno kierownictwo fabryki jaki władze lokalne nie miały przygotowanego planu postępowania awaryjnego mającego na celu minimalizację skutków awarii ani nie miały odpowiedniego wyposażenia ratunkowego.

Przedstawione powyżej awarie wraz z kilkoma innymi, które miały miejsce $\mathrm{w}$ latach siedemdziesiątych i osiemdziesiątych były powodem rozpoczęcia prac legislacyjnych mających na celu opracowanie zasad zwiększających bezpieczeństwo w przemyśle procesowym.

\section{Dokumenty i przepisy związane z zagadnieniami bezpieczeństwa}

W 1998 roku IEC (International Electrotechnical Commission) opracował dokument 61508 zatytułowany "Funkcjonalne bezpieczeństwo elektrycznych /elektronicznych/ programowalnych elektronicznych systemów bezpieczeństwa". Opublikowany dokument ustalał zasady projektowania systemów bezpieczeństwa zarówno dotyczące sprzętu jak i oprogramowania. Dokument poza zaleceniami dotyczącymi projektowania systemów omawia sposoby i metody testowania zarówno na etapie odbioru jak i w czasie pracy produkcyjnej. Norma ta stała się podstawowym dokumentem do opracowania następnych standardów. Trzy kolejne normy związane z zagadnieniami bezpieczeństwa to IEC 61511 dotycząca procesów, IEC 61513 dotycząca energetyki jądrowej oraz IEC 62061 dotycząca produkcji i wyposażenia.

Najważniejszą normą związaną z zagadnieniami bezpieczeństwa procesowego jest IEC 61511. Jest to techniczna norma ustalająca inżynierskie zasady, które gwarantują bezpieczeństwo procesów dzięki stosowaniu systemów odpowiedzialnych za bezpieczeństwo przemysłowych procesów. Systemy takie są określane jako SIS-Safety Instrumented Systems. Norma została zatytułowana: „Functional safety - Safety instrumented systems for the process industry sector". SIS odgrywa podstawową rolę w zapewnieniu bezpiecznej warstwy ochronnej wokół procesu. System ten nazywany jest różnie: SIS, system bezpieczeństwa, system awaryjnego odłączania, system bezpiecznego blokowania (emergency, SRCS - safety related control system, safety shutdown system or safety interlock). Jest to część systemu sterowania maszyny, której zadaniem jest zapobieganie sytuacjom zagrożenia.

SIS to specjalnie zaprojektowane systemy bezpieczeństwa, niezależne od automatyki sterującej przebiegiem procesu, zawierające elementy i zespoły automatyki oraz oprogramowanie. Funkcjonują one przez cały czas w trybie bezpośredniej łączności z procesem wytwórczym (przetwórczym). Zadaniem tych systemów bezpieczeństwa jest podejmowanie natychmiastowych działań, w celu usunięcia skutków wykrytych przez siebie niebezpiecznych zdarzeń zachodzących w procesie. IEC 61511 jest obecnie podstawową normą służącą do projektowania systemów bezpieczeństwa w sektorze procesowym Europejska komisja normalizacyjna, CENELEC (Europejski Komitet Normalizacyjny Elektrotechniki) przyjęła opracowany dokument IEC 61511 jako normę EN 61511. Oznacza to, że w każdym z krajów członkowskich Unii Europejskiej przyjęta norma jest publikowana jako norma krajowa. Tekst normy krajowej odpowiada dokładnie zawartości normy europejskiej. IEC 61511 zawiera wymagania dotyczące stosowania SIS od rozpoczęcia projektu zakładu do ukończenia działalności zakładu. Zawartość normy omawia początkową koncepcję układu bezpieczeństwa, wymagania projektowe, wdrożenie, okres działania, demontaż i utylizację.

W USA normą podstawową do projektowania SIS (systemów bezpieczeństwa) jest dokument ANSI/ISA 84.00.01-2004 wprowadzony we wrześniu 2004, będący odbiciem IEC 61511.

Działania mające na celu ograniczanie negatywnych skutków prowadzenia działalności produkcyjnych doprowadziły do opracowania europejskich regulacji prawnych obowiązujących na terenie ówczesnej Europejskiej Wspólnoty Gospodarczej. Dokumentem tym była dyrektywa 82/501/ EWG z dnia 24 czerwca 1982 roku w sprawie zagrożenia poważnymi awariami przez niektóre rodzaje działalności przemysłowej, zwana dyrektywą Seveso I. Rozwój nauki, przeprowadzone analizy i ocena skuteczności obowiązujących regulacji zaowocowała wprowadzeniem przez Radę Wspólnoty Europejskiej dyrektywy 96/82/WE z dnia 9 grudnia 1996 r. w sprawie kontroli niebezpieczeństwa poważnych awarii związanych z substancjami niebezpiecznymi , zwanej dyrektywą Seveso II. Przepisy wynikające z unijnych aktów prawnych zostały wdrożone do polskiego prawodawstwa m. in. w postaci ustawy "Prawo ochrony środowiska”, Tytuł IV „Poważne awarie”.

\section{Zarządzanie bezpieczeństwem procesowym}

Zarządzanie bezpieczeństwem procesowym skupia się na projektowaniu bezpiecznych linii technologicznych, maszyn i systemów sterujących, analizach ryzyka projektowanych bądź istniejących układów, skutecznych kontrolach procesu, testach i konserwacji urządzeń, procedurach operacyjnych, zarządzaniu zmianami organizacyjnymi, postępowaniu powypadkowym oraz szkoleniu personelu.

Producent maszyny lub instalacji ma obowiązek zapewnienia, że wyrób wprowadzany na rynek Wspólnoty Europejskiej, został zaprojektowany i wytworzony zgodnie z postanowieniami odpowiednich dyrektyw nowego podejścia.

Wszystkie maszyny, poszczególne ich rodzaje lub instalacje spełniać muszą Zasadnicze wymagania bezpieczeństwa, zawarte w Załącznikach do poszczególnych dyrektyw europejskich. Przedstawione powyżej normy nie muszą być stosowane na terenie Unii Europejskiej, ponieważ normy to tylko zalecenia techniczne. Dokumentami prawnymi obowiązującym na terenie Europy są dyrektywy. Stosowanie norm jest jednak jak najbardziej zalecane, bowiem daje gwarancje spełnienia wymagań zasadniczych odpowiednich dyrektyw.

Art. 217 Kodeksu Pracy stanowi, że niedopuszczalne jest wyposażanie na obszarze Rzeczpospolitej Polskiej stanowisk pracy w maszyny i inne urządzenia techniczne, które nie spełniają wymagań dotyczących ich oceny zgodności z zasadniczymi wymaganiami bezpieczeństwa.

Pierwszym krokiem w kierunku zapewnienia bezpieczeństwa projektowanego lub modernizowanego zakładu przemysłowego jest identyfikacja możliwych zagrożeń. Istnieje wiele narzędzi i metod wspomagających identyfikację. Są to $\mathrm{m}$. in. : - wstępna analiza zagrożeń PHA (Preliminary Hazard Analysis),

- badanie zagrożeń i zdolności do działania - HAZOP (Hazard and Operability Studies), 
- listy kontrolne, ocena ekspercka.

Wybór odpowiedniej metody zależy od takich czynników jak: wielkość obiektu, jego złożoność, dostępność danych historycznych czy etap cyklu życia (projektowanie, eksploatacja, modernizacja).

Następnym etapem jest oszacowanie możliwych konsekwencji i prawdopodobieństwa wystąpienia zdarzenia niebezpiecznego. Do tego stosuje się różne techniki jakościowe, półilościowe i ilościowe. Mogą to być:

- procedura analizy rodzajów i skutków uszkodzeń - FMEA (Failure Mode \& Effect Analysis),

- analiza drzewa niezdatności - FTA (Fault Tree Analysis),

- analiza drzewa zdarzeń - ETA (Event Tree Analysis),

- analiza warstw zabezpieczeń - LOPA (Layer of Protection Analysis).

Wybór konkretnej metody znów będzie uzależniony od dostępności parametrów ilościowych, stopnia złożoności procesu i występującej aparatury kontrolno-pomiarowej.

\section{Czynniki techniczne wpływające na bezpieczeństwo procesu}

Bezpieczeństwo maszyny/urządzenia lub procesu zależy głównie od trzech czynników:

- konstrukcji maszyny lub przebiegu procesu,

- zastosowanych rozwiązań systemów sterujących oraz użytych zabezpieczeń,

- stosowanych procedur oraz zachowań ludzkich.

W wielu gałęziach przemysłu jak przemysł chemiczny, energetyka jądrowa, przemysł spożywczy, kosmetyczny, petrochemiczny, główne źródło zagrożenia tkwi często w procesie. Najnowsze kierunki rozwoju systemów bezpieczeństwa to tworzenie systemów wewnętrznie bezpiecznych określanych również konstrukcjami wewnętrznie bezpiecznymi. Proces wewnętrznie bezpieczny stwarza niewielkie zagrożenie nawet w przypadku powstania awarii. Proces taki nie wymaga rozbudowanego układu sterującego odpowiedzialnego za bezpieczeństwo. Często jest przedstawiany jako przeciwieństwo do tych procesów, w których wysoki poziom zagrożeń jest kontrolowany przez sterujące systemy bezpieczeństwa. Przy projektowaniu układów wewnętrznie bezpiecznych usiłuje się nie dopuścić do powstawania zagrożeń zamiast tworzyć systemy kontrolujące te zagrożenia. Dziedzina wiedzy związana z tworzeniem procesów i maszyn wewnętrznie bezpiecznych jest rozwijana dopiero od kilkunastu lat i stosunkowo mało znana projektantom. Konstrukcje wewnętrznie bezpieczne powstają według pewnej filozofii wdrażanej w trakcie tworzenia procesu lub maszyny. Ten sposób myślenia został zapoczątkowany przez Theodora Kletza po wypadku w zakładach chemicznych Nypro Ltd we Flixborough i powinien towarzyszyć cyklom eksploatacji urządzenia, wliczając w to wyprodukowanie, transport, przechowywanie, użycie oraz składowanie późniejszych odpadów.

Są cztery zasady postępowania związane z projektowaniem konstrukcji i procesów wewnętrznie bezpiecznych:

\section{- zamiana,}

Zamiana polega na wyeliminowaniu czynnika lub zastąpieniu go innym, mniej szkodliwym, powodującym mniejsze zagrożenie.

- minimalizacja,

Minimalizacja - zwana także intensyfikacją polega na użyciu mniejszej ilości niebezpiecznych materiałów (w przypadku konieczności ich zastosowania).

- umiarkowanie,

Umiarkowanie - określane również tłumieniem lub ograniczaniem, polega na użyciu materiałów niebezpiecznych w sposób ograniczający stopień ich szkodliwości (poprzez chłodzenie, rozcieńczanie, przetwarzanie w łagodniejszych warunkach).

- upraszczanie,

Upraszczanie - zwane również tolerancją na błędy polega na eliminowaniu skomplikowania. Upraszczanie zmniejsza ryzyko wystąpienia błędów wynikających z czynnika ludzkiego przy obsłudze urządzeń.

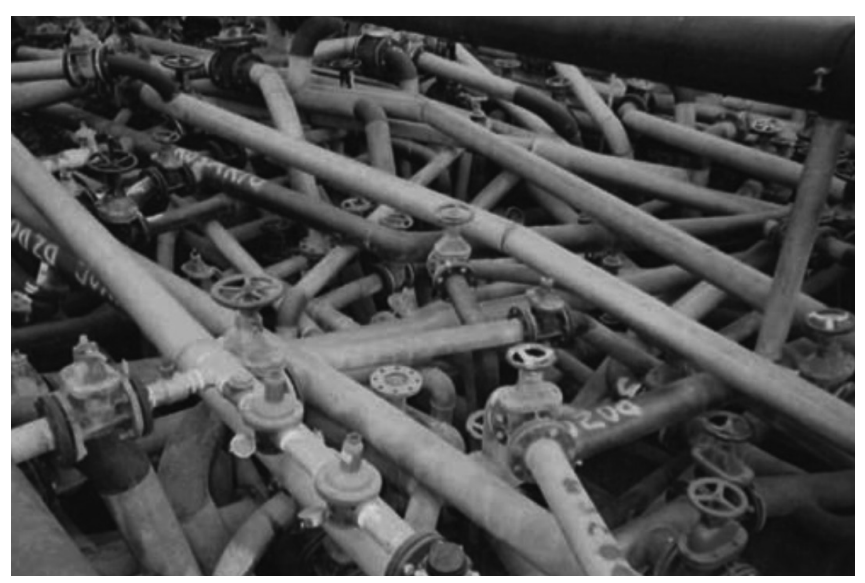

Rys. 4. Przykład niewłaściwie zaprojektowanej instalacji wymagającej uproszczenia

Fig. 4. An example of badly designed process installation

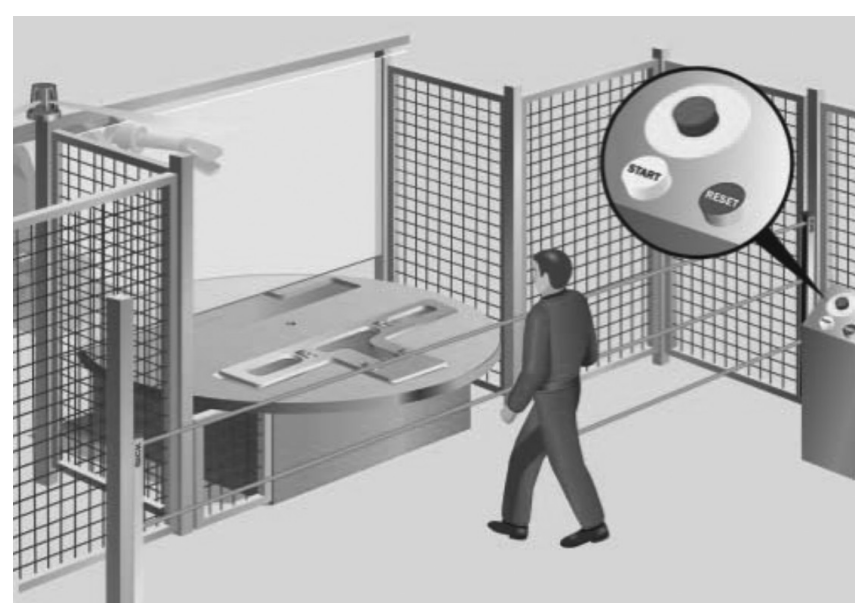

Rys. 5. Przykład zabezpieczenia obszaru niebezpiecznego przed wtargnięciem człowieka [3]

Fig. 5. Protective of human before entering dangerous area

Następna metoda zwiększania bezpieczeństwa polega na niedopuszczaniu pracowników w obszar niebezpieczny tworzony przez pracujące maszyny lub instalacje. Nadzór nad obszarami niebezpiecznymi jest zapewniany przez system osłon stałych i ruchomych, kurtyn świetlnych, skanerów laserowych, system mat bezpieczeństwa, itp. Wejście pracownika w obszar niebezpieczny powinno skutkować zatrzymaniem maszyny lub linii technologicznej.

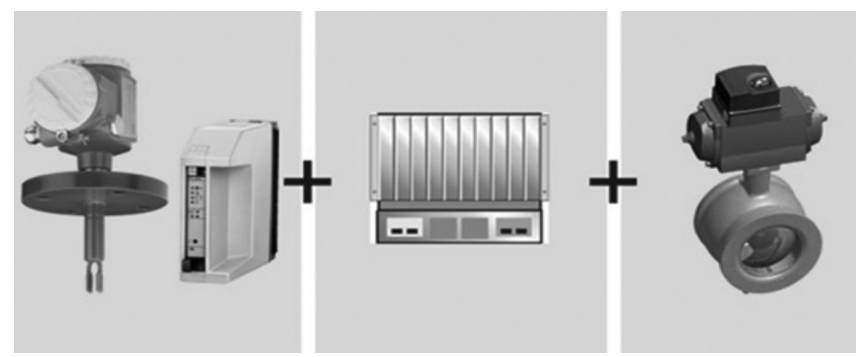

Rys. 6. Przykład aktywnego systemu bezpieczeństwa [5]

Fig. 6. Active safety system 
W wielu przypadkach (zwłaszcza w przemyśle procesowym) pracownik musi przebywać w strefach niebezpiecznych. Bezpieczną pracę systemów zapewniamy tworząc systemy bezpieczeństwa o określonym współczynniku niezawodności działania. Systemy bezpieczeństwa można podzielić na aktywne i pasywne.

W aktywnych systemach bezpieczeństwa występują odpowiednie czujniki informujące o stanach procesu lub maszyny, układy logiczne analizujące bieżącą sytuację i podejmujące odpowiednie decyzje oraz zespoły wykonawcze realizujące te decyzje (rys. 6).

Wyższy poziom bezpieczeństwa, w stosunku do omówionego wcześniej, zapewniają pasywne systemy bezpieczeństwa, bardziej odporne na awarie, aczkolwiek trudniejsze do realizacji, jeszcze rzadko stosowane. Układy te, w przeciwieństwie do aktywnych, mają tę zaletę, że nie potrzebują zasilania. W przypadkach zagrożenia elementy biernego układu bezpieczeństwa inicjują pewne działania, jak zmiana otwarć szczelin dławiących, zalanie układu czy wprowadzenie prętów kontrolnych w rdzenie reaktorów. Działania te wynikają z praw fizyki (rozszerzalność cieplna, prawa grawitacji) i nie mogą nie zadziałać. Takie systemy bezpieczeństwa są bardziej niezawodne w porównaniu z systemami aktywnymi.

Każdy układ sterujący jest złożony z elementów o określonej zawodności. Nie ma elementów ani systemów niezawodnych. Projektant układów odpowiedzialnych za bezpieczeństwo ma obowiązek dopasowania niezawodności działania tego systemu do zagrożeń określonych w procesie oceny ryzyka. Normy IEC 61508 oraz IEC 61511 (normy dla przemysłu chemicznego i procesowego) wymagany stopień ograniczenia ryzyka oraz zdolność systemu do ograniczania ryzyka definiują przez podanie parametru SIL (Safety Integrity Level) nazywanego poziomem nienaruszalności bezpieczeństwa. Występują cztery poziomy SIL. Poziom zapewniający najniższe bezpieczeństwo to poziom SIL 1, natomiast najwyższy stopień bezpieczeństwa gwarantują układy z poziomem SIL 4.

\begin{tabular}{|c|c|}
\hline $\begin{array}{c}\text { Wymagany } \\
\text { poziom SIL }\end{array}$ & Wytworzona ochrona przed zagrożeniami \\
\hline 4 & $\begin{array}{c}\text { Ochrona przed katastroficznymi } \\
\text { zagrożeniami dla społeczności lokalnej }\end{array}$ \\
\hline 3 & $\begin{array}{c}\text { Ochrona przed umiarkowanymi zagrożeniami } \\
\text { dla pracowników i społeczności lokalnej }\end{array}$ \\
\hline 2 & $\begin{array}{c}\text { Zabezpieczenie sprzętu i produkcji, umiarkowany } \\
\text { poziom ochrony zdrowia pracowników }\end{array}$ \\
\hline 1 & Umiarkowane zabezpieczenie urządzeń \\
i procesów
\end{tabular}

Rys. 7. Wymagane poziomy SIL w zależności od wytwarzanych zagrożeń

Fig. 7. Required SIL levels as function of risk

Wzrost bezpieczeństwa ma również związek z opracowaniem oraz stosowaniem odpowiednich procedur. Strategie proceduralne obejmują przestrzeganie standardowych procedur obsługowych, procedur związanych z zasadami bezpieczeństwa, szkolenia i trening pracowników. Procedury powinny dotyczyć zagrożeń spowodowanych z przyczyn technicznych oraz zagrożeń powstałych z powodu zagrożeń środowiskowych bądź działalności ludzkiej.

Ponieważ stosowane zabezpieczenia techniczne nie gwarantują pełnego bezpieczeństwa, w procesach stwarzających zagrożenia dla społeczności lokalnych wymagane jest ponadto stosowanie wielowarstwowych poziomów zabezpieczeń (rys. 8). Jeden poziom zabezpieczeń nie daje gwarancji zapewnienia bezpieczeństwa procesowi lub personelowi, jeśli pojawia się niebezpieczny incydent. Z tego powodu bezpieczeństwo trzeba zapewnić na wielu poziomach zabezpieczeń. Większość pracy wykonanej przez projektanta dotyczącej zagrożenia zawartego w procesie (maszynie) oraz ocena potencjalnego ryzyka jest związana z określeniem wymagań dotyczących redukcji ryzyka oraz przypisaniem tych wymagań do poszczególnych poziomów zabezpieczeń (protection layers).

Wielowarstwowe systemy zabezpieczeń to układy, które nie powinny dopuścić do sytuacji awaryjnej oraz systemy, których działanie powinno wystąpić po zaistnieniu awarii. Układy zabezpieczające przed powstaniem awarii to właściwie zaprojektowany proces, system sterowania przebiegiem procesu, układy bezpieczeństwa - działania operatorów oraz systemy SIS. Do układów które powinny zadziałać po zaistnieniu awarii zaliczamy układy gaśnicze, zraszacze, kurtyny wodne itp.. Zaliczają się tutaj również alarmy, śluzy bezpieczeństwa, procedury oraz przygotowanie personelu zakładowego oraz służb lokalnych, pozazakładowych (służb chemicznych, medycznych, przeciwpożarowych) na wypadek zagrożenia.

Aby wielowarstwowy system zabezpieczeń spełniał funkcje bezpieczeństwa musi być spełniony warunek, że każda warstwa działa niezależnie od pozostałych. Kolejne warstwy nie mogą zawierać elementów (czujniki, zawory, itp.) umieszczonych w innych warstwach.

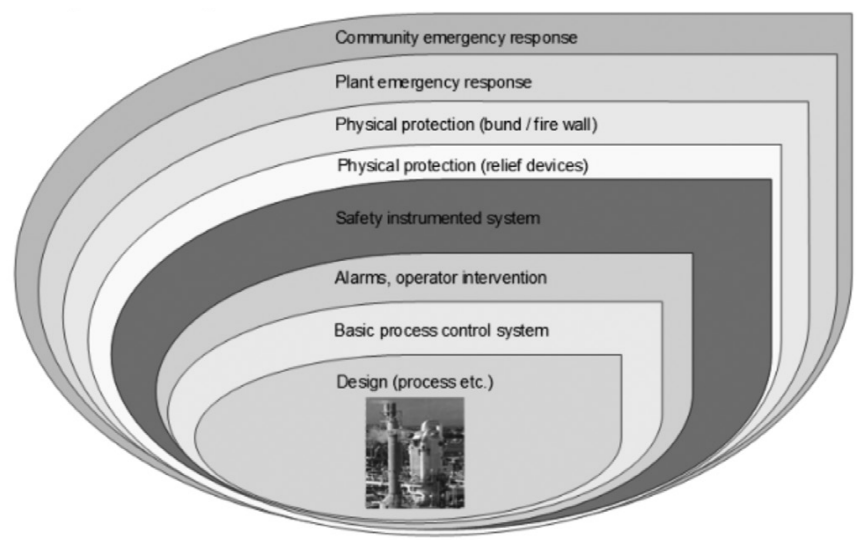

Rys. 8. Schemat pokazujący wielowarstwowe poziomy zabezpieczeń: design- (projekt procesu), basic proces control system-system sterowania procesem, alarms, operator intervention-alarmy i działania obsługi, safety instrumentem system- system odpowiedzialny za bezpieczeństwo, physical protection (relief devices)-urządzenia bezpieczeństwa, physical protection (bund/fire wall)- kurtyny wodne, plant emergency response- zakładowy system ratowniczy, community emergency response- środowiskowe systemy ratunkowe

Fig. 8. Draft of multilayer protection system

Bezpieczeństwo procesowe powinno być w pierwszej kolejności nastawione na niedopuszczenie do wystąpienia zagrożeń. Jeśli pomimo zastosowanych zabezpieczeń nastąpiła katastrofa wówczas należy rozpocząć plan zachowań awaryjnych na terenie zakładu oraz poza terenem a także podjąć działania minimalizujące powstałe straty. Zgodnie z obowiązującym ustawodawstwem do obowiązków zakładu procesowego należy opracowanie planu kryzysowego oraz zabezpieczenie niezbędnego wyposażenia awaryjnego. Należy dodać że plan kryzysowy nie jest fragmentem stałych procedur fabrycznych. Plan ten powinien w trakcie działalności zakładu być cyklicznie rozwijany. Rozwój planu powinien wynikać z gromadzonej wiedzy dotyczącej zachowania instalacji i maszyn w okresie produkcyjnym, 
w okresach testowania wyposażenia, serwisowania i prowadzonych remontów.

Najważniejsza dla przemysłu procesowego EN 61511 zawiera w swoich podstawowych rozdziałach wskazania dotyczące oceny ryzyka projektowanego bądź modernizowanego zakładu oraz zasady projektowania dotyczące systemów sterujących odpowiedzialnych za bezpieczeństwo, zasady wykonania tych systemów oraz ich odbioru. Norma ta jako jeden z pierwszych dokumentów regulacyjnych dla przemysłu procesowego omawia problemy wcześniej pomijane, dotyczące zasad eksploatacji układów bezpieczeństwa. Zagadnienia te, niezwykle ważne z punktu widzenia bezpieczeństwa, dotyczą, w okresie działania zakładu, zasad testowania układów SIS pod kątem sprawdzania ich poprawności działania. Norma omawia też zalecane działania po zaprzestaniu produkcji i na etapie utylizacji maszyn i instalacji procesowych.

\section{Wnioski}

Procesy, nieodłącznie związane z wysokimi temperaturami, ciśnieniami i toksycznymi materiałami stwarzają duże zagrożenia dla pracowników oraz społeczności lokalnej. Po serii poważnych katastrof przemysłowych, w krajach rozwiniętych powstał szereg regulacji technicznych, których celem jest zmniejszenie prawdopodobieństwa zaistnienia katastrofy. Projekt instalacji powinien minimalizować prawdopodobieństwo wystąpienia uszkodzeń mogących prowadzić do niebezpiecznych sytuacji. Rozwiązania techniczne przewidywane w projekcie muszą być zgodne z dobrą sztuką inżynierską. Na wszystkich etapach projektowania i przygotowania procedur obsługowych trzeba uwzględniać problemy współpracy człowieka z obiektem. Złożenie wniosku o dopuszczenie do budowy instalacji zakładowej musi być poprzedzone pełną analizą bezpieczeństwa pracy zakładu. Instalacje muszą być wykonywane zgodnie z przepisami dotyczącymi jakości wykonania. Uruchomienie instalacji musi zostać poprzedzone kompleksową walidacją zbudowanych instalacji i maszyn. Koniecznym etapem jest szkolenie personelu obejmujące pracę w warunkach normalnej eksploatacji i w stanach awaryjnych oraz instrukcje działania awaryjnego i wytyczne działań w stanach awarii.

\section{Literatura}

[1] http://www.industrial-monitor.pl/informacje/bezpieczestwo/3031 bezpieczeństwo procesów przemysłowych.

[2] http://www.kierunekchemia.pl/artykul,5388,

[3] http://www.schmersal.pl

[4] http://en.wikipedia.org/wiki/Industrial_safety_systems

[5] http://www.endress.home.pl

[6] Kramarek W.: Strategia bezpieczeństwa maszyn i instalacji, Journal of machine engineering, Wrocław, 2012.
[7] Kramarek W., Konstrukcje wewnętrznie bezpieczne, Mechanik, nr 4/2015.

[8] Dźwiarek M., Systemy lokalizacji w czasie rzeczywistym w bezpieczeństwie maszyn, Mechanik nr 07/2015.

[9] Kramarek W., Zagadnienia bezpieczeństwa elektrowni jądrowej, Mechanik, nr2/2016, str.125-128. 